\title{
From Living Apart to Living Together: Do Children Born before the Current Partnership Matter?
}

\author{
Roselinde van der Wiel, Clara. H. Mulder, Helga A.G. de Valk
}

\begin{abstract}
This study examines the association between having children born before the current partnership and women's and men's likelihood of transitioning from living apart together (LAT) to co-residing. LAT partnerships are common among individuals with pre-partnership children, but have so far been under-researched. Our study not only focuses on those in LAT relations, but also takes the different pathways to becoming a single parent into account. Event-history analysis was performed using waves 1-4 from the Netherlands Kinship Panel Study.

The results indicate that separated and widowed mothers were less likely to transition to co-residence with their LAT partner than childless women who had previously been in a co-residential union. Mothers who had previous out-of-union children were found to be even less likely to enter co-residence. Results were mostly similar for men and women. The only exception was the effect of being widowed with children; for men this resulted in higher chances of transitioning to co-residence with a new partner whereas for women the chances were lower.

The findings suggest that individuals' parenthood and union histories are associated with the development of their later partnerships, and that these patterns vary by gender. Given contemporary and future patterns of partnership separation, our study provides insights for better understanding how LAT relations develop for different sub-populations.
\end{abstract}

Keywords: Living apart together · Transition to co-residence $\cdot$ Re-partnering Children $\cdot$ Single parents

\section{Introduction}

Single parenthood has become an increasingly common phenomenon in Western countries (Bernardi/Mortelmans 2018). In the Netherlands, almost 15 percent of all children lived in a single-parent household in 2014. However, single parenthood is often a temporary stage in the life course. In most European countries, the majority of single parents enter a new co-residential partnership at some point (Bernardi) 
Mortelmans 2018). A parent's co-residence with a new partner has an undeniable effect on both the parent and the child, for example on the parent's physical and mental health (e.g. Williams et al. 2008) and economic security (e.g. Bzostek et al. 2012 on mothers), as well as on the child's well-being (e.g. Bzostek 2008). It is therefore important to understand how the presence of an individual's own children ${ }^{1}$ that is, children who were born either in a previous union or outside a union - are associated with the parent's likelihood of making the transition from living apart to living together with a new partner (who is not the parent of the children).

Earlier research has shown that being a parent is associated with decisions about union formation with a new partner (e.g. Goldscheider/Sassler 2006; Ivanova et al. 2013). However, most of the existing research on this topic was developed based on a rather restrictive, tripartite model of relationships (Roseneil 2006), whereby people were classified as either single, cohabiting, or married. Based on this model, the transition from singlehood to co-residence (Bernhardt/Goldscheider 2002; Ivanova et al. 2013; Lichter/Graefe 2001) and to marriage (Bennett et al. 1995) have been extensively analysed. Most studies do, however, not make a distinction between starting a relationship and starting co-residence, even though these are different events (exception: Bastin 2019 on partnership transitions of single mothers in Germany). Furthermore, living apart together (LAT) partnerships, and even more so those with pre-partnership children involved, have so far been largely ignored. LAT partnerships refer to established, longer-term couple relationships in which the partners live in separate households (see Haskey 2005; Levin/Trost 1999). In general, LAT can be a way to combine the intimacy of a partnership with some benefits of being alone (Duncan et al. 2013 for Britain; Strohm et al. 2009 for the United States). Reasons for living apart rather than co-residing vary with individuals' life course stages (see, for example, Duncan et al. 2013 for Britain; Liefbroer et al. 2015 for ten European countries; Régnier-Loilier et al. 2009 for France; Strohm et al. 2009 for the United States). These studies show that for younger, childless adults who are not ready to live together yet, LAT is often a temporary stage, whereas it is typically a more longterm choice for older adults who wish to maintain their independence - many of whom have experienced divorce or have been widowed. Caregiving responsibilities for children are a common reason for LAT for single parents. External constraints related to, for example, work locations or housing, are frequently mentioned as a reason to live apart across all stages of the life course.

Only a handful of studies have distinguished LAT as a partnership status and taken being a parent into account in analysing the formation of new co-residential partnerships. These include studies that focused on LAT relations after divorce in Belgium (Pasteels/Mortelmans 2013, 2015), the likelihood of living apart versus together with a new partner after divorce or widowhood in the Netherlands (de Jong Gierveld/Merz 2013), intentions to live together (Lewin 2018; Poortman/Hewitt 2015), and the transition to co-residence in Germany (Krapf 2017; Wagner et al. 2019) and

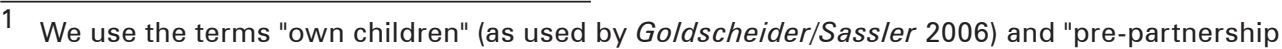
children" interchangeably. 
France (Régnier-Loilier 2016). The results of these studies suggest that being a parent reduces the likelihood that a person will start co-residence with a new partner, or will have the intention to do so. At a time when the number of single parents is increasing, this paper focuses on the association between having own children and the likelihood of an individual making the transition from living apart to living together with a partner. We add to the literature in three ways. First, we take into account the different pathways into single parenthood (separation, widowhood, or out-of-union childbearing). ${ }^{2}$ The distinctions between these pathways have been largely ignored in previous research, even though they are an important source of diversity among single parents (Bernardi/Larenza 2018). Second, we compare single parents with people who are childless. Finally, while most studies have focused exclusively on women, our study examines the gendered nature of these processes by including men as well as women. The inclusion of men in research on this topic is essential given that non-resident father involvement (Westphal et al. 2014) and co-parenting arrangements (Poortman/van Gaalen 2017) are becoming increasingly common in the Netherlands.

The analyses are based on all four waves of the Netherlands Kinship Panel Study (NKPS). We performed discrete-time event-history analysis, with the transition from LAT to co-residence as the event of interest, and an indicator of union history combined with the pathway to single parenthood as the key independent variable. The NKPS data provide detailed information that is rarely available in other datasets, but include relatively few men and women in LAT partnerships. Our study therefore cannot provide strong tests of hypotheses, but serves as one of the first to explore the potentially gendered transition from living apart to living together, the link with the paths into single parenthood and the role of own children.

\section{Background}

Drawing upon past research on the subject, we argue that the presence of an individual's own children may be either negatively or positively associated with their likelihood of making a transition from LAT to co-residence. In general, motivations for making a transition to co-residence among those in LAT partnerships may be related to a desire for more intimacy and spending time together, the wish to form a family (also given social norms prescribing that co-residence should precede parenthood), and practical considerations such as pooling resources. Regardless of motivations, it has been argued that co-residential partnerships generally involve more partner commitment than LAT partnerships do (see, for example, Kamp Dush/ Amato 2005; Lois et al. 2010). We therefore start from and build upon theoretical

2 We use "partnership" to refer to any type of couple relationship, regardless of whether it is coresidential or LAT. Co-residential partnerships are also referred to as unions, and include marriage and unmarried cohabitation. Separation and widowhood refer to past unions, not to past LAT partnerships. 
arguments concerning different levels of commitment in partner relationships and different motivations for making the transition to co-residence between those with and those without own children.

\subsection{Why parenthood may be negatively associated with the transition to co-residence: different life phases, protection of family life, dyadic power, and costs of co-residence}

There are different theoretical mechanisms that may explain why partners with own children may be more or less likely to transition from LAT to co-residence than those without children. First, those without children are in a different life-course phase than those with children. It is likely that many of them are motivated to become parents and form a family with their partner. This motivation might be even stronger among those with previous union experience, because they might feel a greater urgency to become parents after this did not happen in their previous union. In contrast, many of those with children might not feel the need to have more children.

Second, the literature suggests that parents' (perceived) responsibilities for their children can be a reason for refraining from co-residence with a new partner. This reluctance can be fuelled by the wish to maintain a stable family situation, but also, for example, to avoid the interference of a new partner in the parent's child-rearing practices, to prevent the children from growing too attached to a new partner, or to accommodate the wishes of the children when they do not approve of the new partner (Lampard/Peggs 1999; Levin/Trost 1999; Levin 2004). These findings suggest that parents prioritise the wellbeing of their own children, and that being in a new partnership may be attractive as long as this relationship does not affect their own children too much. Living apart together can be seen as a way of being in a partnership while protecting the home environment of an individual's co-resident children (Levin/Trost 1999; Levin 2004). In the following, we refer to this reasoning as the "protection of family life" argument.

The results of a mixed-methods study by De Jong Gierveld and Merz (2013) in the Netherlands confirmed that parents' decisions about whether to co-reside with a new partner after divorce or widowhood are influenced by such considerations even after children have reached adulthood. Indeed, it has been found that compared to childless individuals, both female and male single parents are less likely to have the intention to co-reside with (Lewin 2018 for 11 European countries; Poortman/Hewitt 2015 for the Netherlands) or marry (Reimondos et al. 2011 for Australia) their LAT partner. The protection of family life argument may, however, apply to mothers more than to fathers. Parents with co-resident children, who are predominantly women, could feel more hesitant about introducing a new partner to the household than parents with non-resident children, who are predominantly men. Moreover, gender expectations about work and care may result in women being more inclined than men to prioritise the well-being of their children above their own. In line with this reasoning, the recent work of Thomas et al. (2017a/b) has suggested 
that fathers are more likely than mothers to shift their priorities away from their prior family ties when they re-partner.

A third argument for why we would expect to observe differences in the likelihood of transitioning to co-residence between LAT partners who do and do not have own children is grounded in the greater dyadic power (or the bargaining advantage) of the new partner if they are childless (see Guttentag/Secord 1983 for a discussion of these concepts). The greater dyadic power of the new childless partner results from their stronger position on the partner market; i.e., compared to single parents, whose desirability and "marriageability" are seen as limited, childless individuals have more potential alternative partners available to them (Goldscheider/Kaufman 2006 for both fathers and mothers; Qian et al. 2005 for mothers; Stewart et al. 2003 for fathers). The new childless partner may be reluctant to form a more highly committed partnership with the single parent (Guttentag/Secord 1983). Given the childless partner's power advantage, the likelihood that the partners will enter coresidence may thus be reduced. A single parent, by contrast, may have a more limited choice of partners, and may thus settle for a sub-optimal partner. Uncertainty about whether a match is optimal may also be a reason for postponing co-residence until the parent is more convinced of the partner's suitability, or for rejecting co-residence with the partner entirely (van der Wiel et al. 2018). Some evidence suggests that the position of single fathers on the partner market is more favourable than that of single mothers, as women tend to be more willing than men to be a stepparent (Bernhardt/Goldscheider 2002; Goldscheider/Kaufman 2006; Goldscheider/Sass/er 2006). Again, these findings indicate that the patterns in transitioning from LAT to co-residence are different for fathers and mothers.

Finally, co-residence can be costly for both the parent and the partner. For the new partner, co-residing with someone who has their own children is associated with additional emotional, social, and financial costs (Lichter/Graefe 2001). In considering whether to accept the role of stepparent, women seem to be more concerned about taking on care responsibilities, while men tend to be more worried about taking on financial responsibilities (Lampard/Peggs 1999 for Great Britain). LAT can offer an alternative to co-residence that is associated with less commitment and lower costs. Moreover, for single parents, the lower demands and expectations of LAT arrangements may be seen as desirable, providing conditions that enable them to continue investing resources in their own children, whether co- or non-resident (compare also the interview findings by Lampard/Peggs 1999).

It should also be noted that for single parents, the transition from LAT to co-residence may come at a cost. For example, in the Netherlands, single parents receive tax benefits and financial support, which they risk losing when they are registered with a co-residential partner (Tweede Kamer 2017). The potential loss of welfare income may act as a disincentive to co-residence, although conclusive evidence that this is the case is lacking. Kalmijn and Monden (2010) found that among single mothers in the Netherlands, receiving welfare reduced the likelihood of marriage, but was not associated with the likelihood of cohabitation; possibly because, unlike marriage, cohabitation arrangements do not have to be officially registered. In addi- 
tion, in the United States, Bennett et al. (1995) found a negative, but non-significant effect of receiving welfare on the likelihood of transitioning to marriage.

Again, these cost-related arguments may be more important for mothers and their new partners than for fathers, because mothers are more likely than fathers to be co-residing with their own children.

Overall, these theoretical arguments lead us to expect that women and men with own children are less likely to transition from LAT to co-residence than those who are childless. This expectation concerns parents who have younger co-resident own children in particular. Ivanova et al. (2013) showed for several countries in Europe that a single parent's chances of re-partnering were less affected when the youngest child was over 18 years old.

\subsection{Why parenthood may be positively associated with the transition to co-residence: economic needs, family norms, and the opportunity for parenthood}

There could, however, also be reasons why a single parent would transition more rapidly than a childless person from LAT to co-residence with a new partner. It has been suggested that for single parents in poor economic circumstances in particular, co-residence could create a more stable emotional and financial situation. Separation, which is the most common pathway into single parenthood, negatively affects the partners' economic circumstances. This is particularly true for women, in part because the mother generally becomes the custodial parent in the Netherlands (Poortman 2000). Entering a new co-residential partnership can be a strategy for coping with the financial consequences of separation (de Regt et al. 2013 for Belgium; Dewilde/Uunk 2008 for eleven European countries).

Furthermore, a desire to follow the prevailing social norms that a two-parent family is best-suited for raising children may motivate parents to transition from LAT to co-residence. This is especially likely in a country like the Netherlands, where large shares of the population still hold traditional views on family life. In a 2008 survey conducted in the Netherlands, 74 percent of respondents agreed that a child needs a home with a mother and a father to grow up happily, and 35 percent of respondents disapproved of a woman wanting to be a single mother outside of a stable partnership (EVS 2010). Social norms have considerable influence on the formation and the development of partnerships (see, for example, Arosio 2010; Lewis 1973). Thus, pressure from societal norms and parents' own views on family life could increase parents' likelihood of transforming a LAT partnership into a co-residential one. Given the gendered norms regarding work and childcare responsibilities in the Netherlands (see, for example, Yerkes/Visser 2006), we may expect that this argument applies mostly to women.

Finally, it has been posited that some people may be attracted by the opportunity of "instant parenthood" by entering a relationship with a person who already has own children. Bennett et al. (1995) made this argument for the male partners of single mothers. Since men have less control than women over the decision to become a parent because they cannot bear children themselves, co-residing with 
a mother and her children can be an alternative way to fulfilling a desire for (step-) fatherhood (Goldscheider/Kaufman 2006). Goldscheider and Kaufman (2006) found some support for this argument, but Bennett et al. (1995) did not (both in the United States). Similarly, Goldscheider and Kaufman (2006) speculated that some women may want to have children, but dread the idea of being pregnant and bearing a child. For these women, stepmotherhood could offer an alternative route to becoming a parent, thereby making them more likely to transition from LAT to co-residence with a new partner who has own children.

Based on these theoretical arguments concerning the economic needs, social norms, and opportunities for parenthood, we might expect the opposite of what we argued in Section 2.1, namely that women and men with own children are more likely to transition from LAT to co-residence than those who are childless. In the empirical part of the paper, we will explore the direction of the relationship between having own children and the transition to co-residence in our sample.

Furthermore, based on our literature review and the existing empirical evidence, we expect to find that the effect of having own children is gendered. Both the negative and the positive effects of having own children may be greater for the transition to co-residence for mothers than for fathers. The effects of having own children are probably also greater when the children are younger than when they are older.

\subsection{Pathways to single parenthood}

Previous studies have only started to address the role of the diversity of the pathways to single parenthood (Bernardi/Larenza 2018). However, the theoretical arguments on the factors that stimulate or inhibit the transition from LAT to co-residence may depend on how the partners became single parents. We explore this diversity by distinguishing between parents who are separated, widowed, or had a child outside of a union. For separated parents, the desire to avoid another painful separation or problematic co-residential experience - both for themselves and for their children - can be a reason to avoid making a full commitment to a new partner, and to instead remain in a long-term living apart together arrangement (Levin 2004 for Sweden; van der Wiel et al. 2018 for the Netherlands).

Widowed parents may also be afraid or hesitant to commit fully to a new partner by moving in together. Having experienced the painful loss of a beloved partner could cause the parent to seek to maintain distance when starting a new relationship. Moreover, continued loyalty to a deceased partner can hinder the development of a new partnership (Stevens 2002). Stevens has suggested that this loyalty may be the reason why some widowed people refrain from co-residing with a new partner. Furthermore, in many cases, the partnership preceding widowhood involved intensive caregiving tasks for the partner, especially for women (see, for example, DiGiacomo et al. 2013; Hebert/Schulz 2006). Hence, there is evidence that widows, but not widowers, perceive being relieved of the responsibility to care for their deceased partner as an advantage of living alone (Davidson 2001 for the United Kingdom). It has also been shown that widowers are more likely than widows to 
say they want a new partnership, but often feel constrained in finding a new partner by their age and poor health (Davidson 2001).

Clearly, the experiences of widowed and separated single parents are very different. It is not immediately obvious how these differences might lead to differences in their likelihood of transitioning to co-residence. For two reasons, it could be easier for widowed parents than for separated parents to introduce a new partner to the household. First, whereas the other parent is likely still involved and enacting a parenting role in the children's lives when the parents are separated, there could be more room or even a greater need and desire for a new (co-residential) parent figure in the lives of the children of widowed parents. Second, the children of widowed parents appear to have fewer behavioural problems and higher levels of well-being than the children of divorced parents in the Netherlands (Spruijt et al. 2001). It should be noted, however, that most of the existing literature on this topic has compared widowed and separated individuals in general, rather than parents specifically. Wu and Schimmele (2005) found that in Canada, widowed people had lower chances of re-entering a co-residential partnership than separated people did. It has also been shown that among those in LAT relationships, widowed individuals were relatively unlikely to move in together (Régnier-Loilier 2016). Similarly, De Jong Gierveld and Merz (2013) found that widowhood made parents in the Netherlands more likely to choose LAT over co-residence when re-partnering.

The third way of becoming a single parent is through out-of-union childbearing (that is, not with a co-residential partner). This pathway to single parenthood is observed almost exclusively among women. It is rather uncommon in the Netherlands; in 2012, only 8 percent of children in the Netherlands were born into a singleparent household (Loozen et al. 2014). Mothers of children born outside of a union may face social stigma (see, for example, Wiegers/Chunn 2015). Because of this stigma, men may try to keep their romantic involvement with these mothers private by maintaining separate households, and they may be reluctant to increase the level of commitment in a relationship. Such a reluctance of men to commit to this specific group of single mothers would go against a positive effect of social norms on family life leading to conformance to the two-parent family standard (see previous section). Moreover, the fact that these women followed an alternative path to family formation could signal that they have a general lack of interest in living with a partner.

A recent study by Bastin (2019) on single mothers' partnership and household formation in Germany looked at women's partnership contexts before single motherhood. The author found few significant differences between the pathways into single motherhood, but women who were unpartnered when they became a single mother had a significantly higher hazard of moving in with their LAT partner than the other single mothers (but at the same time had relatively low relationship formation rates). It is so far unclear whether this is also true in other contexts, and for men and women alike. Based on the literature outlined above, our study aims to explore the potentially different patterns of transition from LAT to co-residence based on the origins of single parenthood among women and men. 


\subsection{Other factors associated with the transition to co-residence}

We accounted for several other factors that have been found to be associated with the transition from LAT to co-residence in earlier research. Having co-resided with another partner in the past has been shown to affect people's current relationships, even though these findings are inconsistent. Bernhardt and Goldscheider (2002) showed, for example, that having been previously married was a positive, significant predictor of entering a new union. However, Poortman (2007) found that the chances of union formation were significantly lower for those who were re-partnering than for those who were forming their first union.

The effect of partnership duration on the chances of co-residing has been found to be non-linear. In two German studies, partners who had been living apart for a short time only or for longer than two years were shown to be less likely to start co-residence than those who had been living apart for one or two years (Krapf 2017; Wagner et al. 2019). Previous studies on the transition from LAT to co-residence also found a negative (Régnier-Loilier 2016) or non-linear, inverted U-shaped (Krapf 2017; Wagner et al. 2019) effect of age.

Furthermore, the ages of the partners are relevant in this context, as findings from in-depth interviews (van der Wiel et al. 2018) and survey data (Liefbroer et al. 2015) have suggested that living apart tends to be a transitory stage for younger individuals, but is often a longer-term or permanent state for older individuals.

People who are highly educated and employed may be less likely to co-reside with a partner because they have relatively little to gain from such an arrangement, and face higher opportunity costs of co-residence (Konietzka/Tatjes 2014). Furthermore, the literature suggests that it is important to take into account whether an individual lives in an urban or rural area (e.g. Bennett et al. 1995; Coulter/Hu 2017; Kalmijn/Monden 2010).

As the characteristics of the partner may be associated with an individual's likelihood of transitioning to co-residence, we include information on the partner's age, educational attainment, and employment status. Additionally, we account for whether the partner had own children. Bernhardt and Goldscheider (2002) found that having co-resident children was negatively associated with women's likelihood of union formation, unless it was with a partner who had co-resident children himself; whereas for men having co-resident children mattered less. Goldscheider and Sassler (2006) found that for men, having own children was associated with a lower likelihood of forming a union only if they did not live with their children, and the potential union was with a childless woman.

Finally, distance between LAT partners was found to be negatively associated with the likelihood of entering co-residence in Germany in the study by Krapf (2017). However, it was not possible to incorporate this predictor in our analyses owing to data limitations. 


\section{Data, measures, and methods}

\subsection{Data and sample}

We use the Netherlands Kinship Panel Study (NKPS) (Dykstra et al. 2005; Dykstra et al. 2012; Hogerbrugge et al. 2015; Merz et al. 2012). The NKPS is a multi-actor panel study of four waves, each spaced three years apart, which started in 2002/2004 with an initial sample of 8,161 Dutch-speaking men and women between the ages of 18 and 79 (Dykstra et al. 2005). The response rate of the NKPS at wave one was 45 percent. Response rates in the Netherlands tend to be lower than in other Western industrialised countries (de Leeuw/de Heer 2002). The initial sample size of 8,161 dropped to 2,382 in wave four, after follow-up interviews without refreshment. For more information on non-response in the NKPS, see the metadata (e.g., Merz et al. 2012). All analyses in this paper are based on unweighted data. We explored the extent to which panel attrition was selective with respect to partnership status, parenthood status, age, and employment status, and concluded that this was not the case (full details available upon request from the first author). For example, respondents in LAT partnerships at wave one did not differ significantly from cohabiting respondents in their likelihood of non-response in wave two (Dykstra et al. 2012).

Respondents in LAT partnerships were identified in the survey as those who responded affirmatively to the question "Do you have a partner at the moment, that is to say, someone with whom you have had a relationship for at least three months?" and then answered negatively to the question "Does your partner live with you here?" For childless women and both childless men and men with own children, LAT relationships make up roughly 20 percent of all person-months spent without a co-residential partner - the other 80 percent are spent in singlehood. For women with own children, the share in LAT is lower, at 13 percent. Given that, once in LAT, those with own children spend on average more time in it than those without, this lower percentage suggests that mothers are less likely than childless women to enter LAT in the first place.

The dependent variable was whether the person started co-residence with their partner in one of the subsequent waves. Our sub-sample included all LAT partnership spells that existed at the time of wave one, or that started afterwards. The observation window started in the month of the first interview. This implies that some of these spells were left-censored. We kept these spells in the dataset in order to retain as many observations as possible. In the discrete-time analyses with piecewise constant hazards that we perform, left-censored cases can be included without technical difficulties. We include a time-varying categorical variable indicating the duration of the spell in a piecewise constant way.

Observations were treated as right-censored after the last interview, the start of co-residence, or the end of the partnership. Having a child with the current LAT partner was another reason for censoring, but this situation was rare $(n=25$ previously childless women, $\mathrm{n}=19$ previously childless men, $\mathrm{n}=11$ women with own children, and $\mathrm{n}=3$ men with own children). Fathers with out-of-union children were excluded from the analyses because of the very small number of such cases $(n=3)$. Further- 


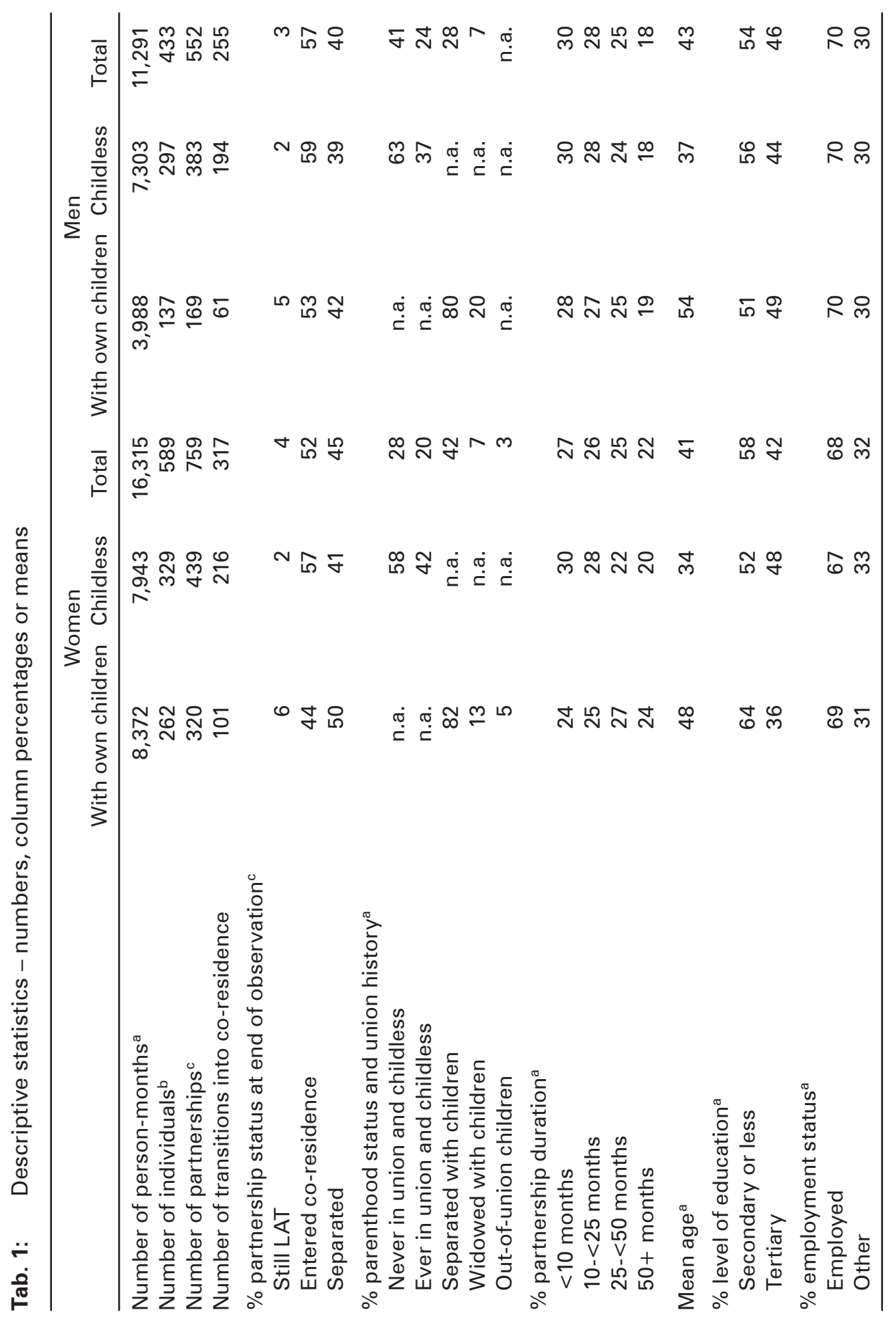


126 - Roselinde van der Wiel, Clara. H. Mulder, Helga A.G. de Valk

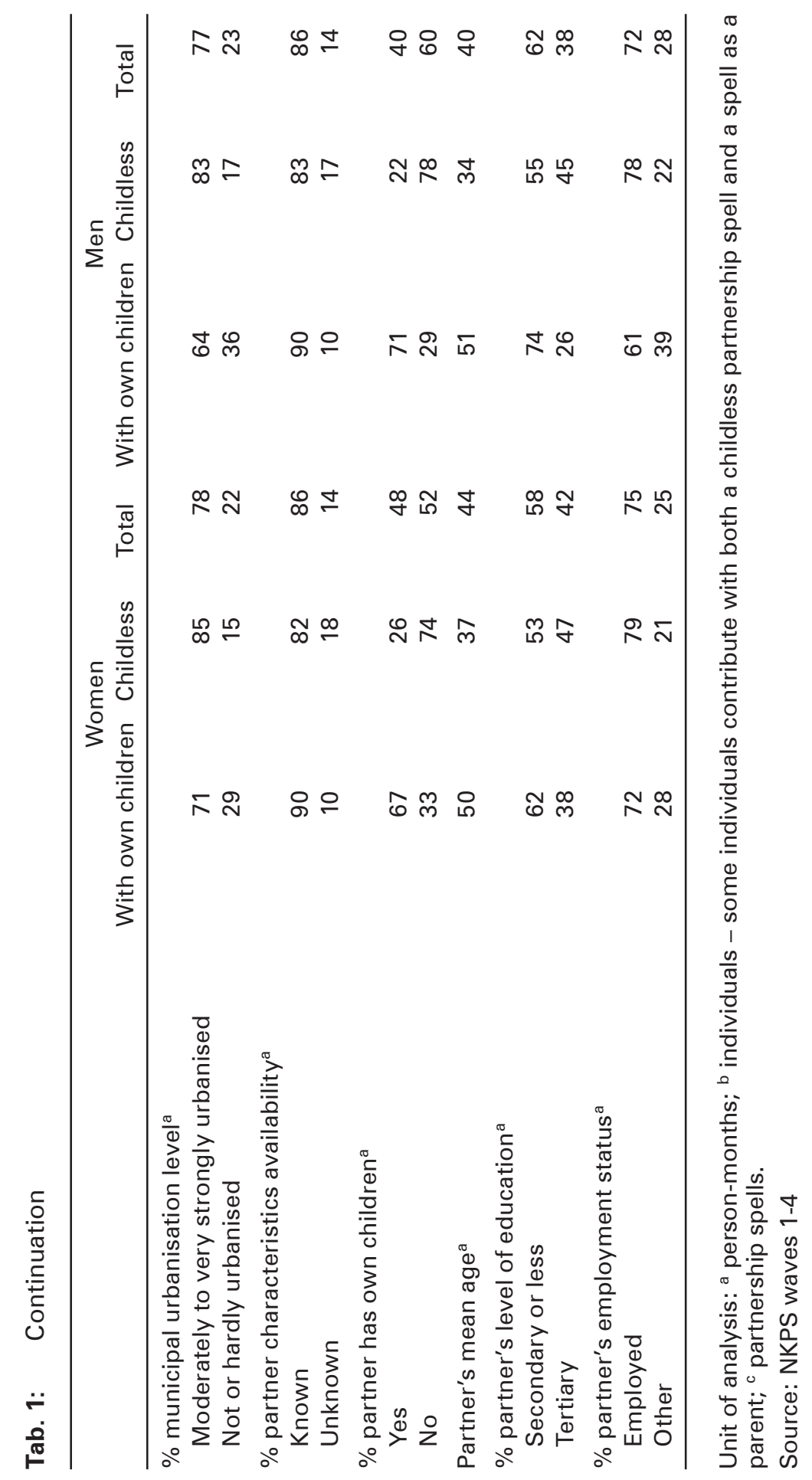


more, the data were truncated after partnership durations of more than 100 months, because the population at risk and the number actually starting co-residence was minimal after this duration. At the end of observation, only a small minority of our population was still living apart together - most had either entered co-residence or separated (see Table 1).

Our analyses covered 27,606 person-months in 1,311 LAT partnerships of 1,022 men and women and 572 transitions into co-residence (see the first rows of Table 1). The descriptive statistics in Table 1 show that, especially among women, individuals with own children made up a significant share of those in LAT partnerships (in line with previous studies based on other data and countries: Reimondos et al. 2011; Upton-Davis 2012).

\subsection{Measures}

The dependent variable was whether or not a transition from LAT to co-residence occurred. No distinction was made between married and unmarried unions because only a few transitions from LAT to marriage occurred ( $n=31$ among women and $\mathrm{n}=28$ among men). The key independent variable was a combination of parenthood status and union history, and was updated monthly. Respondents were classified as one of the following: never in a union and childless, ever in a union and childless, ${ }^{3}$ with out-of-union children, separated with children, or widowed with children (only living biological or adopted children were taken into account). Although prior research has shown the relevance of distinguishing between co-resident, part-time resident, and non-resident children (e.g. Goldscheider/Sass/er 2006), the small sample size did not allow for such distinctions.

The following time-varying independent variables were updated at each wave (but treated as constant between interview waves): educational attainment $(0=$ up to secondary education or $1=$ tertiary education), employed (0) or not employed (1), and residence in a moderately to strongly urbanised (1) or less urbanised (0) municipality. The time-varying control variables, which were updated monthly, are age and duration of the partnership. In addition, we accounted for whether the partners had own children, as well as for the age, educational attainment, and employment status of the partners. See Table 1 for the distribution of these variables in the sample as a whole, and by parenthood status.

Information about the partners' socio-demographic characteristics was frequently missing. For example, this information was not recorded when a partnership started and ended between waves, when the partnership status was corrected during a later interview, or was missing at random. When the partner information was missing in one wave but available for the same partner in the previous or the next wave, we resorted to the nearest record available. When the age of the partner was missing, it was imputed using the median partner's age of the women or the

3 Given the small number of widowed childless women, it was not possible to distinguish these women from separated childless women. 
men with the same parenthood status and union history. At this point, a remaining 10 percent of person-months had missing values for the partner's employment status and educational attainment, and 12 percent of person-months had missing values for the partner's parenthood status (levels were the same for women and men). A dummy variable "partner characteristics unknown" indicates such cases. See Appendix 1 for a report on the coding of partnership status, partnership duration, and parenthood status.

\subsection{Methods}

Kaplan-Meier survival analysis was used for the visualisation of the timing of transitions from LAT to co-residence. Next, discrete-time event-history analysis was performed with the transition from LAT to co-residence as dependent variable, employing a logistic regression of person-months (Yamaguchi 1991). To adjust for the possible clustering of partnerships within individuals, we calculated robust standard errors. Similar analyses were conducted for our sample of women and men separately.

\section{$4 \quad$ Results}

\subsection{Descriptive statistics}

Figure 1 shows the estimated proportion of women and men in LAT over time, and visualises the differences between those with and without own children in combination with different union histories in terms of the timing of their transition to coresidence. The figure shows that women and men with own children were slower to enter co-residence with their LAT partner than those who are childless. After two years in the partnership, only 11 percent of widowed women with children, 18 percent of women with out-of-union children, and 26 percent of separated women with children were estimated to have entered co-residence. It should be noted, however, that the numbers of widowed mothers $(n=30)$ and of mothers with out-of-union children $(n=14)$ were small. In comparison, 32 percent of childless women who were never in a union and 44 percent of childless women who were ever in a union had entered co-residence by that point in time. Although similar overall patterns are observed for men, the level of diversity among men was lower. However, we still find that those with own children were the slowest to enter co-residence. The estimates show that after two years, 29 percent of widowed and separated men with children were estimated to have entered co-residence, compared with 36 percent of childless men who had never been in a union and 44 percent of childless men who had been in a union before. It should be noted here as well that the number of widowers was small $(n=26)$. 
Fig. 1: Kaplan-Meier estimates of the timing of the transition from LAT to coresidence over time, by parenthood status and union history
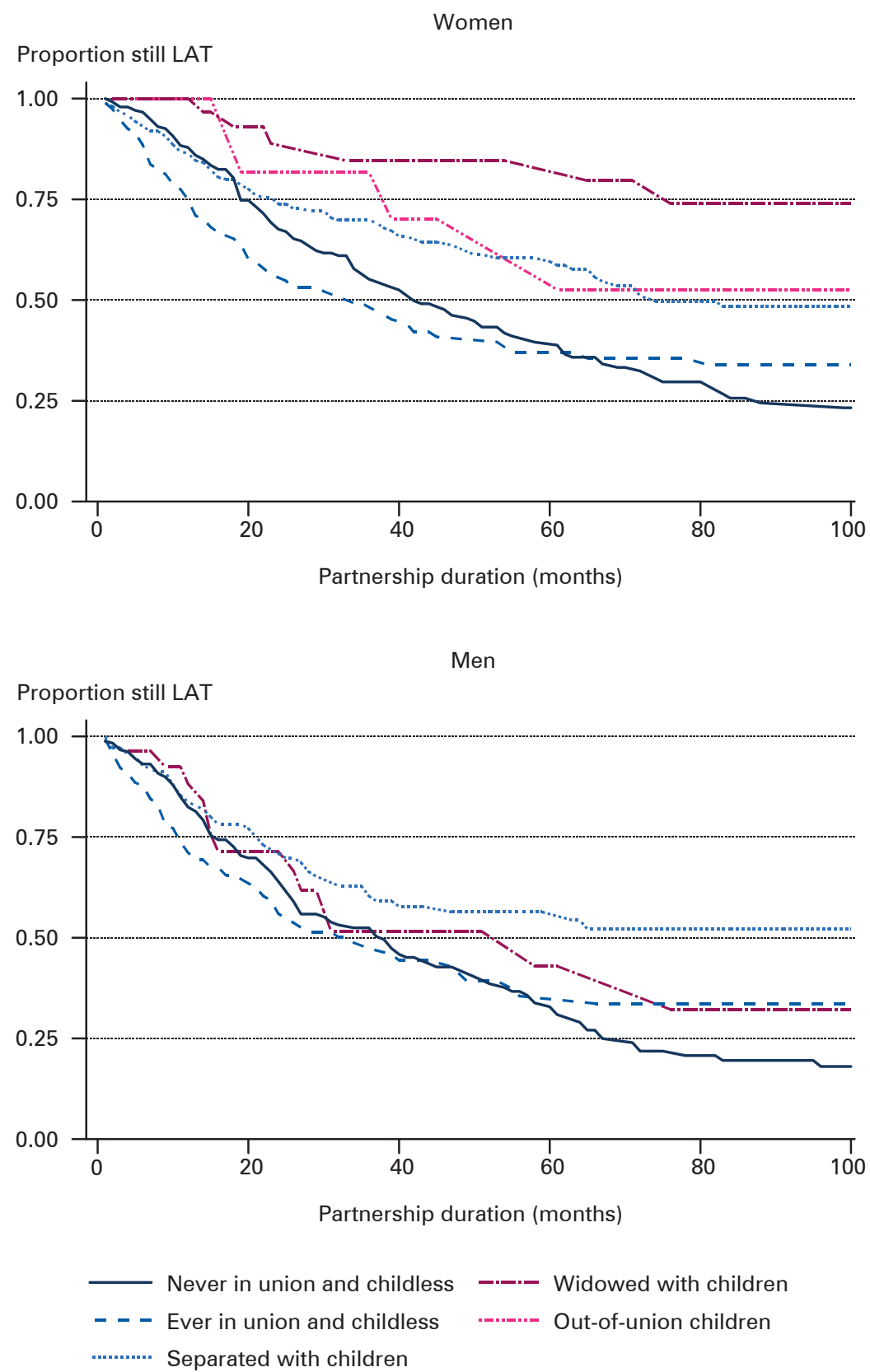

Source: NKPS waves 1-4 


\subsection{Multivariate analyses: the role of own children}

The results from discrete-time event-history analysis (see Table 2) largely confirm the differences shown in Figure 1, and support our expectation based on protection of family life, dyadic power, and costs of co-residence for women. Separated women with children were estimated to be 35 percent $((1-0.645) * 100$ percent) less likely to enter co-residence with their LAT partner than childless women who were ever in a union; this difference was statistically significant $(p=0.011)$. Widowed women with children $\left(\mathrm{e}^{\mathrm{b}}=0.423, p=0.087\right)$ and women with out-of-union children $\left(\mathrm{e}^{\mathrm{b}}=0.366\right.$, $p=0.108$ ) were estimated to be even less likely to start co-residence than childless women who were previously in a union. However, these differences were not or only marginally statistically significant, probably due to the small sample sizes of these categories.

Tab. 2: Transition from LAT to co-residence. Logistic regression (odds ratios, coefficients, $p$-values)

\begin{tabular}{|c|c|c|c|c|c|c|}
\hline & \multicolumn{3}{|c|}{ Women } & \multicolumn{3}{|c|}{ Men } \\
\hline & $e^{b}$ & $\mathrm{~b}$ & $p$ & $e^{b}$ & b & $p$ \\
\hline \multicolumn{7}{|c|}{ Parenthood status and union history (ref. ever in union and childless) } \\
\hline Never in union and childless & 0.792 & -0.234 & 0.112 & 0.814 & -0.206 & 0.219 \\
\hline Separated with children & $0.645^{* *}$ & -0.439 & 0.011 & 0.841 & -0.173 & 0.444 \\
\hline Widowed with children & $0.423^{*}$ & -0.860 & 0.087 & 1.812 & 0.595 & 0.161 \\
\hline Out-of-union children & 0.366 & -1.004 & 0.108 & n.a. & n.a. & n.a \\
\hline \multicolumn{7}{|c|}{ Partnership duration (ref. $10-<25$ months) } \\
\hline$<10$ months & $0.620 * * *$ & -0.478 & 0.001 & $0.696 * *$ & -0.362 & 0.026 \\
\hline $25-<50$ months & $0.667^{* *}$ & -0.405 & 0.011 & 0.829 & -0.187 & 0.285 \\
\hline $50+$ months & $0.668^{* *}$ & -0.403 & 0.026 & $0.641^{*}$ & -0.445 & 0.060 \\
\hline \multicolumn{7}{|l|}{ Age (ref. 35-44) } \\
\hline $18-24$ & 0.819 & -0.200 & 0.470 & 0.863 & -0.148 & 0.639 \\
\hline $25-34$ & $1.661 * * *$ & 0.508 & 0.006 & $1.479 *$ & 0.392 & 0.052 \\
\hline $45-54$ & 0.772 & -0.258 & 0.202 & 0.789 & -0.237 & 0.298 \\
\hline $55-64$ & 0.766 & -0.266 & 0.465 & 0.787 & -0.240 & 0.498 \\
\hline $65+$ & 0.182 & -1.703 & 0.110 & 0.742 & -0.299 & 0.620 \\
\hline Tertiary education & 0.955 & -0.046 & 0.711 & 1.166 & 0.153 & 0.293 \\
\hline Not employed & $0.765^{*}$ & -0.268 & 0.092 & $0.611 * *$ & -0.492 & 0.014 \\
\hline Urban residential environment & 0.861 & -0.150 & 0.295 & 0.865 & -0.145 & 0.425 \\
\hline Partner characteristics unknown & $0.409 * * *$ & -0.894 & 0.001 & $0.346 * * *$ & -1.061 & 0.000 \\
\hline Partner has own children & 0.900 & -0.105 & 0.530 & 0.812 & -0.208 & 0.299 \\
\hline Partner's age & $0.978^{* *}$ & -0.022 & 0.023 & $0.976^{* *}$ & -0.025 & 0.032 \\
\hline Partner tertiary education & 1.008 & 0.008 & 0.947 & 0.927 & -0.076 & 0.593 \\
\hline Partner not employed & 0.964 & -0.036 & 0.842 & 0.846 & -0.168 & 0.346 \\
\hline
\end{tabular}

${ }^{*} p<0.1,{ }^{* *} p<0.05,{ }^{* * *} p<0.01$

Source: NKPS waves 1-4 
The regression results for men suggest that, in line with what we found for women, men who were separated with children may be less likely to start co-residence than childless men who had previously been in a union $\left(\mathrm{e}^{\mathrm{b}}=0.841, p=0.444\right)$. However, the estimated effect is smaller than it is for women and the coefficient does not reach statistical significance (please note that we use the term "effect" as a convenient shorthand for statistical associations, without necessarily implying causality). In contrast to their female counterparts, widowed men with children were estimated to be 1.8 times more likely to start co-residence than childless men who were previously in a union $\left(e^{\mathrm{b}}=1.812, p=0.161\right)$. Despite the large effect, this difference was not statistically significant, which is likely because of the small number of widowed men with children $(n=26)$. Thus, although the data do not provide the statistical power to draw any firm conclusions, our findings do suggest a gradient between different categories of parenthood status and union history.

The results from a regression model on pooled data for men and women including an interaction term between sex and parenthood status/union history partly confirm our expectation on gender differences in the effects of having own children (see Table 3). The gender difference in the impact of being widowed with children, as opposed to being childless and previously in a union, which was found in the separate analyses for men and women, is convincingly confirmed by the interaction model $\left(e^{b}=4.465, p=0.010\right)$. The results further provide some indication that being separated with children may indeed have a smaller negative effect for men than for women $\left(\mathrm{e}^{\mathrm{b}}=1.308, p=0.291\right)$.

The bivariate and multivariate findings point in different directions. Whereas the Kaplan-Meier estimates suggest that widowed mothers were less likely than women with out-of-union children to enter co-residence, the regression results suggest the

Tab. 3: Transition from LAT to co-residence. Logistic regression, model with interaction term (odds ratios, coefficients, $p$-values)

\begin{tabular}{llll}
\hline & $\mathrm{e}^{\mathrm{b}}$ & $\mathrm{b}$ & $p$ \\
\hline Parenthood status and union history (ref. ever in union and childless) & & & \\
$\quad$ Never in union and childless & 0.810 & -0.211 & 0.130 \\
Separated with children & $0.648^{* *}$ & -0.433 & 0.009 \\
Widowed with children & $0.435^{*}$ & -0.833 & 0.083 \\
Out-of-union children & 0.375 & -0.982 & 0.113 \\
Man & 0.910 & -0.094 & 0.580 \\
Interaction term & & & \\
$\quad$ Never in union and childless * Man & 0.989 & -0.011 & 0.956 \\
Separated with children * Man & 1.308 & 0.269 & 0.291 \\
Widowed with children * Man & $4.465^{* *}$ & 1.496 & 0.010 \\
\hline
\end{tabular}

${ }^{*} \mathrm{p}<0.1,{ }^{* *} \mathrm{p}<0.05,{ }^{* * *} \mathrm{p}<0.01$

Notes: Same control variables as in Table 2, results not shown. No parameter estimated for men with out-of-union children because the category is empty.

Source: NKPS waves 1-4 
opposite. Stepwise modelling (not shown) indicated that compositional differences in terms of age and employment status explain these contradictory findings: widowed mothers were older and less often employed, and were therefore found less likely to enter co-residence than women with out-of-union children in the KaplanMeier analysis. The Kaplan-Meier results for men indicated that those who were widowed transitioned to co-residence more slowly than those who were childless and were previously in a union. However, after controlling for the ages of the men and their partners in the regression model, widowed men in fact appear more likely to enter co-residence than any other category in the parenthood status and union history variable.

Based on our analyses, we cannot draw firm conclusions about differences between childless persons with and without prior union experience. The KaplanMeier estimates do however suggest that for shorter partnership durations, those childless persons who were previously in a union are quicker to enter co-residence than those who were not, but that this pattern reverses at longer partnership durations (Fig. 1). The regression results show a moderately negative but non-significant effect of being childless and without prior union experiences (women: $e^{b}=0.792$, $p=0.112$; men: $\mathrm{e}^{\mathrm{b}}=0.814, p=0.219$ ).

The results show little evidence of an effect of the partner having own children, although the coefficients point in the expected negative direction (women: $\mathrm{e}^{\beta}=0.900, p=0.530 ;$ men: $\left.\mathrm{e}^{\beta}=0.812, p=0.299\right)$. To gain a better understanding of the role of having own children for each partner, we estimated an additional model that investigated whether the likelihood of starting co-residence differed depending on whether only the female partner, only the male partner, both partners, or neither of the partners had own children (not in table; results available upon request from first author). The likelihood of women starting co-residence was not found to be associated with the male partner having own children. Furthermore, women who had children and whose partner had own children as well were not found to be significantly more or less likely to start co-residence than women who had own children but whose partner did not $\left(\mathrm{e}^{\mathrm{b}}=0.948, p=0.821\right)$. The likelihood of men starting coresidence was shown to be 45 percent lower when both partners, rather than only the male partner, had own children $\left(e^{\mathrm{b}}=0.551, p=0.044\right)$. However, whether only the male partner, only the female partner, or both partners had children as opposed to neither partner was not found to make a significant difference in men's likelihood of entering co-residence. Thus, we did not replicate previous findings that the effect of having own children on the likelihood of starting co-residence depended on whether the partner also had children (Bernhardt/Goldscheider 2002; Goldscheider) Sassler 2006).

To test whether the effects of having own children on the likelihood of transitioning to co-residence differed between parents of minor and adult children, we ran a model on a sample of parents only (see Appendix 2, Table A1). Mothers whose youngest child was aged 22 or older were estimated to be almost twice as likely to enter co-residence with their LAT partner as mothers whose youngest child was aged 10-21 ( $\left.\mathrm{e}^{\mathrm{b}}=1.970, p=0.140\right)$. Given the large effect, the non-significance is likely due to the small sample. For women, children's age is a reasonable indicator of 
their residence status, given that the vast majority of minor children live with their mothers and it is almost exclusively older children who are non-resident. In line with previous findings by Ivanova et al. (2013), our result suggests that when children are older and thus likely to have left the parental home, they matter less for their mother's partnership choices. Of course, the age of the mother partly captures this effect in the main analysis, as her age and that of her children are correlated. The number of children (1 or $2+)$ and whether the youngest child was under age 22 or under age 10 was not found to make a difference; effects were very small and $p$-values very large. For fathers, the age of the youngest child (aged 22 or older compared to aged 10-21) was less strongly associated with the transition to co-residence than for mothers $\left(\mathrm{e}^{\mathrm{b}}=1.305, p=0.572\right)$. Most fathers' children are non-resident, regardless of their age. We refer to Appendix 2, Table A2 for the mean age of the individual and of the youngest child as well as the average number of children, for each group of union history and parenthood status. As one would expect, widowed fathers and mothers are on average about 10-15 years older than their separated counterparts, and so are their children. Hardly any difference in the average number of children is found between respondents with different union histories and parenthood statuses.

\subsection{Control variables}

We further observe that the likelihood of entering co-residence was strongly associated with the duration of the partnership, and was highest between 10 and 25 months after couple formation (Table 2). This finding corresponds with the results found by Krapf (2017) for Germany. As expected, the transition to co-residence was shown to be age-graded. This relationship followed an inverse U-shape, with women and men aged 25-34 being the most likely to make the transition, and those aged $65+$ being the least likely. For the age of the partner, we found a modest but significant negative effect (women: $\mathrm{e}^{\mathrm{b}}=0.978, p=0.023$; men: $\mathrm{e}^{\mathrm{b}}=0.976, p=0.032$ ). The partner's age squared made no significant contribution to the model, and using a categorical specification for the partner's age also yielded no significant results.

Individuals who were not employed were shown to be less likely to start co-residence than those who were employed (women: $\mathrm{e}^{\mathrm{b}}=0.752, p=0.066$; men: $\mathrm{e}^{\mathrm{b}}=0.611$, $p=0.014)$. Furthermore, we found that when the partner's information was unknown, the likelihood of starting co-residence was significantly lower. The other control variables for both women/men and their partners were not found to have any sizeable or significant association with the likelihood of starting co-residence.

\section{$5 \quad$ Discussion and conclusion}

We studied the associations between having own children and the likelihood of entering co-residence with a LAT partner for both women and men. Getting insight into these patterns is crucial given the large and increasing number of single parents in many countries, and the fact that many of these parents will enter a new partnership. This paper contributes to the literature by focusing on individuals in 
LAT relationships, which is a common partnership type among women and men with own children. Furthermore, we provide in-depth analyses of how parenthood status and union history are associated with the likelihood of transitioning from LAT to a co-residential union. It should be noted that we do not make any causal claims, even though in our discussion of the results we sometimes use the term "effect" for readability.

The Kaplan-Meier survival analysis and event-history analysis suggested that women with own children may be less likely to make the transition from living apart to living together with a partner than childless women with prior union experience are. If they did so at all, it took them a relatively long time. This finding seems to be in line with the protection of family life argument, which states that mothers may choose to have a new partner, but also want to protect their children from any possible negative effects of the partnership. The results may also reflect the perceived additional costs of co-residence and the dyadic power advantage of the male partners. Our findings echo those of Krapf (2017), Régnier-Loilier (2016) and Wagner et al. (2019) for Germany and France.

It appears that not just the presence of children, but the event at the onset of single motherhood (separation, widowhood, or out-of-union childbearing) is associated with women's likelihood of transitioning to co-residence. The results suggest that separated mothers are somewhat more likely to start co-residence than widowed mothers. Mothers who had children outside of a union before the current partnership had the lowest estimated likelihood of making a transition. This finding may indicate that these women were less interested than the other mothers in being in a co-residential partnership. We must note, however, that the differences between mothers with different pathways into single motherhood are not statistically significant. This could be due to our small sample, and calls for future studies including this information to replicate our work.

Bastin's (2019) study also illustrated the relevance of pathways into single motherhood for partnership and household formation. Her finding that single mothers who were unpartnered at the time of birth had a relatively high risk of moving in with a LAT partner seems contrary to our finding at first. However, being unpartnered is not the same as being out-of-union. The category single mothers with out-of-union children in our study includes women who had a child within a prior LAT partnership. This history of living apart from a partner even in the situation of having children together might indicate a particularly strong preference for LAT. The example demonstrates the importance of clear definitions and terminology in research. Using qualitative methods, the partnership preferences of these women having children without a steady or a co-residential partner could be further explored.

The results for men were by and large similar to those for women, but did not always reach statistical significance. Our findings seem to suggest that men who are separated with children may be less likely to start co-residence than childless men who have also been in a union before; this negative association seems to be smaller for men than for women. Widowhood may have a different meaning for men and women, in that this pathway was positively associated with the likelihood of entering co-residence for men, and negatively for women. These findings suggest 
that, similar to what was found in previous studies (e.g. Ivanova et al. 2013), having own children matters less in the union formation processes of men than of women. However, the current study could not provide clear evidence for this, due to limited statistical power.

Our finding that women with own children seem less likely to transition from LAT to co-residence than their childless counterparts with prior union experience may signify a path of relatively low family stability for themselves and their children, as LAT partnerships are generally less stable than co-residential partnerships (Asendorpf 2008). Family instability has been shown to be associated with negative outcomes for children's well-being (e.g. Osborne/McLanahan 2007). Having a new partner is less intrusive for children when the partner does not live in the same household. Thus, by living apart from her partner, the relationship between the mother and her child is managed and protected (Levin 2004). It would be interesting for future studies to investigate what happens to these mothers when their children have reached adulthood and are no longer living with them. Our additional analyses have suggested that there were some differences by the age of the child, but we could not analyse this issue in depth. It may, however, be relevant to learn more about how these mothers catch up and start new or different types of partner relationships later in life, and how these relationships are associated with their wellbeing, and that of their children.

While the NKPS provided rich data on partnership and fertility histories for our event-history analysis, the desire for a detailed specification of parenthood status and union history resulted in our study having limited statistical power. In this light, we emphasise that non-significant findings must be interpreted with caution and that they can neither be taken as conclusive support for the substantive hypothesis, nor as evidence that the null hypothesis is true. It would be useful to replicate and further develop this exploration using other large datasets or cross-national data collections, such as the Generations and Gender Survey. A larger sample would also allow for a distinction between the transition to cohabitation and the transition to marriage. A further limitation of our data was that they did not allow us to determine whether parents were (re-)entering a relationship with the father or the mother of their children, which could have advanced the transition to co-residence. Another limitation is that co-resident children could not be distinguished from non-resident children and part-time resident children. Although this information is recorded in the data, we could not use it because of small numbers. With a larger sample and more detailed information on the timing of the start and end of partnerships, it might also be possible to explore how some partnerships start immediately upon the ending of a previous partnership, or even earlier.

It would be interesting to investigate the transition from singlehood to a LAT partnership, or directly to a co-residential partnership, in further research on the effect of parenthood on union formation. Future research could also explore the underlying mechanisms that explain the effect of having own children on union formation and union transitions, for example through in-depth interviews. As with most survey data, we were not able to test these mechanisms using NKPS data. Despite these limitations and the need for further research, our results suggest that 
individuals' parenthood and union histories play a part in the ways in which their subsequent partnerships develop, and that there are gender differences in these patterns. In times of increasingly complex and pluriform families, with many men, women, fathers, and mothers experiencing the break-up of a union at least once, living apart together may well offer an attractive alternative to singlehood, cohabitation, and marriage for a growing number of people. Future studies should therefore go beyond the standard family typologies to better capture the experiences of people who are in LAT partnerships.

\section{Acknowledgements}

We thank Prof. Dr. Alessandra de Rose for her feedback at the early stages of this paper, as a thesis supervisor of Roselinde van der Wiel during the European Doctoral School of Demography. Moreover, we thank Miriam Hils and the language editors of CPoS for valuable language editing. The research for this paper is part of the project "Family ties that bind: A new view of internal migration, immobility and labourmarket outcomes" (FamilyTies). The project is led by principal investigator Clara $\mathrm{H}$. Mulder (University of Groningen), and has received funding from the European Research Council (ERC) under the European Union's Horizon 2020 research and innovation programme (grant agreement No 740113).

\section{References}

Arosio, Laura 2010: The heterogamy effect: Does it really exist? A study on partner selection and marital breakdown in contemporary Italy. Paper presented at the XVII Isa World Congress of Sociology: Gothenburg. Sweden.

Asendorpf, Jens B. 2008. Living apart together: Alters- und Kohortenabhängigkeit einer heterogenen Lebensform. In: Kölner Zeitschrift Für Soziologie Und Sozialpsychologie 60,4: 749-764 [doi: 10.1007/s11577-008-0035-4].

Bastin, Sonja 2019: Single mothers' new partners: Partnership and household formation in Germany. In: Journal of Marriage and Family 81,4: 991-1003 [doi: 10.1111/ jomf.12575].

Bennett, Neil G.; Bloom, David E.; Miller, Cynthia K. 1995: The influence of nonmarital childbearing on the formation of first marriages. In: Demography 32,1: 47-62 [doi: 10.2307/2061896].

Bernardi, Laura; Larenza, Ornella 2018: Variety of transitions into lone parenthood. In: Bernardi, Laura; Mortelmans, Dimitri (Eds.): Lone parenthood in the life course. Cham: Springer International Publishing: 93-108 [doi: 10.1007/978-3-319-63295-7_5].

Bernardi, Laura; Mortelmans, Dimitri; Larenza, Ornella 2018: Changing lone parents, changing life courses. In: Bernardi, Laura; Mortelmans, Dimitri (Eds.): Lone parenthood in the life course. Cham: Springer International Publishing: 1-26 [doi: 10.1007/9783-319-63295-7_1].

Bernhardt, Eva; Goldscheider, Frances 2002: Children and union formation in Sweden. In: European Sociological Review 18,3: 289-299 [doi: 10.1093/esr/18.3.289]. 
Bzostek, Sharon H. 2008: Social fathers and child well-being. In: Journal of Marriage and Family 70,4: 950-961 [doi: 10.1111/j.1741-3737.2008.00538.x].

Bzostek, Sharon H.; McLanahan, Sara S.; Carlson, Marcia J. 2012: Mothers' repartnering after a nonmarital birth. In: Social Forces 90,3: 817-841 [doi: 10.1093/sf/sos005].

Coulter, Rory; Hu, Yang 2017: Living apart together and cohabitation intentions in Great Britain. In: Journal of Family Issues 38,12: 1701-1729 [doi: 10.1177/0192513X15619461].

Davidson, Kate 2001: Late life widowhood, selfishness and new partnership choices: A gendered perspective. In: Ageing and Society 21: 297-317 [doi: 10.1017/ S0144686X01008169].

de Jong Gierveld, Jenny; Merz, Eva-Maria 2013: Parents' partnership decision making after divorce or widowhood: The role of (step)children. In: Journal of Marriage and Family 75,5: 1098-1113 [doi: 10.1111/jomf.12061].

de Leeuw, Edith D.; de Heer, Wim 2002: Trends in household survey nonresponse: A longitudinal and international comparison. In: Groves, Robert et al. (Eds.): Survey nonresponse. New York: Wiley: 41-54.

de Regt, Sabrina; Mortelmans, Dimitri; Marynissen, Tinne 2013: Financial consequences of relationship dissolution: A longitudinal comparison of formerly married and unmarried cohabiting men and women. In: Sociology 47,1: 90-108 [doi: 10.1177/0038038512453793].

Dewilde, Caroline; Uunk, Wilfred 2008: Remarriage as a way to overcome the financial consequences of divorce: A test of the economic need hypothesis for European women. In: European Sociological Review 24,3: 393-407 [doi: 10.1093/esr/jcn025].

DiGiacomo, Michelle et al. 2013: Transitioning from caregiving to widowhood. In: Journal of Pain and Symptom Management 46,6: 817-825 [doi: 10.1016/j.jpainsymman.2013.01.005].

Duncan, Simon et al. 2013: Why do people live apart together? In: Families, Relationships and Societies 2,3: 323-338 [doi: 10.1332/204674313X673419].

Dykstra, Pearl A. et al. 2005: Codebook of the Netherlands kinship panel study, a multiactor, multimethod panel study on solidarity in family relationships, wave 1. NKPS working paper no. 4. The Hague: Netherlands Interdisciplinary Demographic Institute.

Dykstra, Pearl A. et al. 2012: Codebook of the Netherlands kinship panel study, a multiactor, multi-method panel study on solidarity in family relationships, wave 2. NKPS Working Paper No. 8. The Hague: Netherlands Interdisciplinary Demographic Institute.

EVS 2010: European values study 2008: Netherlands (EVS 2008).

Goldscheider, Frances; Kaufman, Gayle 2006: Willingness to stepparent: Attitudes about partners who already have children. In: Journal of Family Issues 27,10: 14151436 [doi: 10.1177/0192513X06289646].

Goldscheider, Frances; Sassler, Sharon 2006: Creating stepfamilies: Integrating children into the study of union formation. In: Journal of Marriage and Family 68,2: 275291 [doi: 10.1111/j.1741-3737.2006.00252.x].

Guttentag, Marcia; Secord, Paul F. 1983: Too many women? The sex ratio question. Beverly Hills, CA: Sage Publication.

Haskey, John 2005: Living arrangements in contemporary Britain: Having a partner who usually lives elsewhere and living apart together (LAT). In: Population Trends 122: 35-45.

Hebert, Randy S.; Schulz, Richard 2006: Caregiving at the end of life. In: Journal of Palliative Medicine 9,5: 1774-1187 [doi: 10.1089/jpm.2006.9.1174]. 
Hogerbrugge, Martijn J. A. et al. 2015: Codebook of the Netherlands Kinship Panel Study, a multi-actor, multi-method panel study on solidarity in family relationships, wave 4. NKPS Working Paper No. 13. The Hague: Netherlands Interdisciplinary Demographic Institute.

Ivanova, Katya; Kalmijn, Matthijs; Uunk, Wilfred 2013: The effect of children on men's and women's chances of re-partnering in a European context. In: European Journal of Population 29,4: 417-444 [doi: 10.1007/s10680-013-9294-5].

Kalmijn, Matthijs; Monden, Christiaan 2010: Poverty and union formation among nevermarried single mothers in the Netherlands, 1989-2005. In: Population Studies 64,3: 263-274 [doi: 10.1080/00324728.2010.506244].

Kamp Dush, Claire M.; Amato, Paul R. 2005: Consequences of relationship status and quality for subjective well-being. In: Journal of Social and Personal Relationships 22,5: 607-627 [doi: 10.1177/0265407505056438].

Konietzka, Dirk; Tatjes, André 2014: Two steps of union formation: First intimate relationships and first coresidential unions in the life courses of the German cohorts 1971-1973 and 1981-1983. In: Journal of Youth Studies 17,8: 1077-1096 [doi: 10.1080/13676261.2014.888405].

Krapf, Sandra 2017: Moving in or breaking up? The role of distance in the development of romantic relationships. In: European Journal of Population 34,3: 313-336 [doi: 10.1007/ s10680-017-9428-2].

Lampard, Richard; Peggs, Kay 1999: Repartnering: The relevance of parenthood and gender to cohabitation and remarriage among the formerly married. In: The British Journal of Sociology 50,3: 443-465 [doi: 10.1111/j.1468-4446.1999.00443.x].

Levin, Irene 2004: Living apart together: A new family form. In: Current Sociology 52,2: 223-240 [doi: 10.1177/0011392104041809].

Levin, Irene; Trost, Jan 1999: Living apart together. In: Community, Work \& Family 2,3: 279-294 [doi: 10.1080/13668809908412186].

Lewin, Alisa C. 2018: Intentions to live together among couples living apart: Differences by age and gender. In: European Journal of Population 34,5: 721-743 [doi: 10.1007/ s10680-017-9446-0].

Lewis, Robert A. 1973: Social reaction and the formation of dyads: An interactionist approach to mate selection. In: Sociometry 36,3: 409-418 [doi: 10.2307/2786342].

Lichter, Daniel T.; Graefe, Deborah Roempke 2001: Finding a mate? The marital and cohabitation histories of unwed mothers. In: Wolfe, Barbara; Wu, Lawrence L. (Eds.): Out of wedlock: Causes and consequences of nonmarital fertility. New York: Russell Sage Foundation: 317-343.

Liefbroer, Aart C.; Poortman, Anne-Rigt; Seltzer, Judith 2015: Why do intimate partners live apart? Evidence on LAT relationships across Europe. In: Demographic Research 32,8: 251-286 [doi: 10.4054/DemRes.2015.32.8].

Lois, Daniel; Kunz, Christina; Kopp, Johannes 2010: "Verliebt, verlobt, verheiratet." Institutionalisierungsprozesse in Liebesbeziehungen junger Erwachsener und Jugendlicher [„In love, engaged, married.“ Institutionalisation processes in love relationships of young adults and youths]. In: Walper, Sabine; Wendt, Eva (Eds.): Partnerschaften und die Beziehungen zu Eltern und Kindern. Befunde zur Beziehungs- und Familienentwicklung in Deutschland. Würzburg: Ergon: 55-84.

Loozen, Suzanne; Pool, Marina; Harmsen, Carel 2014: In wat voor gezinnen worden kinderen geboren? [In what type of families are children born?]. In: Bevolkingstrends, 2e kwartaal: 2-11. 
Merz, Eva-Maria et al. 2012: Codebook of the Netherlands Kinship Panel Study, a multiactor, multi-method panel study on solidarity in family relationships, wave 3 . NKPS Working Paper No. 10. The Hague: Netherlands Interdisciplinary Demographic Institute.

Osborne, Cynthia; McLanahan, Sara 2007: Partnership instability and child well-being. In: Journal of Marriage and Family 69,4: 1065-1083 [doi: 10.1111/j.1741-3737.2007.00431.x].

Pasteels, Inge; Mortelmans, Dimitri 2013: Gescheiden en dan? Herpartneren in Vlaanderen anno 2010 [Divorced and then what? Repartnering in Vlaanderen in 2010]. In: Relaties En Nieuwe Gezinnen 3: 1-66.

Pasteels, Inge; Mortelmans, Dimitri 2015: Dyadic analysis of repartnering after divorce. Do children matter? Zeitschrift Für Familienforschung - Journal of Familiy Research 27: 143-164 [doi: 10.2307/j.ctvddzmht.11].

Poortman, Anne-Rigt 2000: Sex differences in the economic consequences of separation: A panel study of the Netherlands. In: European Sociological Review 16,4: 367 383 [doi: 10.1093/esr/16.4.367].

Poortman, Anne-Rigt 2007: The first cut is the deepest? The role of the relationship career for union formation. In: European Sociological Review 23,5: 585-598 [doi: 10.1093/esr/jcm024].

Poortman, Anne-Rigt; Hewitt, Belinda 2015: Gender differences in relationship preferences after union dissolution. In: Advances in Life Course Research 26: 11-21 [doi: 10.1016/j.alcr.2015.07.002].

Poortman, Anne-Rigt; van Gaalen, Ruben 2017: Shared residence after separation: A review and new findings from the Netherlands. In: Family Court Review 55,4: 531-544 [doi: 10.1111/fcre.12302].

Qian, Zhenchao; Lichter, Daniel T.; Mellott, Leanna M. 2005: Out-of-wedlock childbearing, marital prospects and mate selection. In: Social Forces 84,1: 473-491 [doi: 10.1353/sof.2005.0117].

Régnier-Loilier, Arnaud 2016: Partnership trajectories of people in stable non-cohabiting relationships in France. In: Demographic Research 35,40: 1169-1212 [doi: 10.4054/ DemRes.2016.35.40].

Régnier-Loilier, Arnaud; Beaujouan, Eva; Villeneuve-Gokalp, Catherine 2009: Neither single, nor in a couple. A study of living apart together in France. In: Demographic Research 21,4:, 75-108 [doi: 10.4054/demres.2009.21.4].

Reimondos, Anna; Evans, Ann; Gray, Edith 2011: Living-apart-together (LAT) relationships in Australia. In: Family Matters 87: 43-55.

Roseneil, Sasha 2006: On not living with a partner: Unpicking coupledom and cohabitation. In: Sociological Research Online 11,3: 1-14 [doi: 10.5153/sro.1413].

Spruijt, Ed; de Goede, Martijn; van der Valk, Inge 2001: The well-being of youngsters coming from six different family types. In: Patient Education and Counseling 45,4: 285-294 [doi: 10.1016/S0738-3991(01)00132-X].

Stevens, Nan 2002: Re-engaging: New partnerships in late-life widowhood. In: Ageing International 27,4: 27-42 [doi: 10.1007/s12126-002-1013-1].

Stewart, Susan D.; Manning, Wendy D.; Smock, Pamela J. 2003: Union formation among men in the U.S.: Does having prior children matter? In: Journal of Marriage and Family 65,1: 90-104 [doi: 10.1111/j.1741-3737.2003.00090.x].

Strohm, Charles Q. et al. 2009: "Living apart together" relationships in the United States. In: Demographic Research 21,7: 177-214 [doi: 10.4054/demres.2009.21.7]. 
Thomas, Michael J.; Mulder, Clara H.; Cooke, Thomas J. 2017a: Geographical distances between separated parents: A longitudinal analysis. In: European Journal of Population 34,4: 463-489 [doi: 10.1007/s10680-017-9437-1].

Thomas, Michael J.; Mulder, Clara H.; Cooke, Thomas J. 2017b: Linked lives and constrained spatial mobility: The case of moves related to separation among families with children. In: Transactions of the Institute of British Geographers 42,4: 597-611 [doi: 10.1111/tran.12191].

Tweede Kamer 2017: Miljoenennota 2017. Rijksoverheid [https://www.rijksoverheid.nl/ documenten/begrotingen/2016/09/20/miljoenennota-2017, 24.03.2020.]

Upton-Davis, Karen 2012: Living apart together relationships (LAT): Severing intimacy from obligation. In: Gender Issues 29,1-4: 25-38 [doi: 10.1007/s12147-012-9110-2].

van der Wiel, Roselinde; Mulder, Clara H.; Bailey, Ajay 2018: Pathways to commitment in living-apart-together relationships in the Netherlands: A study on satisfaction, alternatives, investments and social support. In: Advances in Life Course Research 36: 13-22 [doi: 10.1016/j.alcr.2018.03.001].

Wagner, Michael et al. 2019: The transition from living apart together to a coresidential partnership. In: Advances in Life Course Research 39: 77-86 [doi: 10.1016/j. alcr.2018.12.002].

Westphal, Sarah Katharina; Poortman, Anne-Rigt; van der Lippe, Tanja 2014: Non-resident father-child contact across divorce cohorts: The role of father involvement during marriage. In: European Sociological Review 30,4: 444-456 [doi: 10.1093/esr/jcu050].

Wiegers, Wanda A.; Chunn, Dorothy E. 2015: Stigma and resistance: The social experience of choosing sole motherhood in Canada 1965-2010. In: Women's Studies International Forum 51: 42-55 [doi: 10.1016/j.wsif.2015.05.001].

Williams, Kristi; Sassler, Sharon; Nicholson, Lisa M. 2008: For better or for worse? The consequences of marriage and cohabitation for single mothers. In: Social Forces 86,4 : 1481-1511 [doi: 10.1353/sof.0.0057].

Wu, Zheng; Schimmele, Christoph M. 2005: Repartnering after first union disruption. In: Journal of Marriage and Family 67,1: 27-36 [doi: 10.1111/j.0022-2445.2005.00003.x].

Yamaguchi, Kazuo (Ed.) 1991: Discrete-time logit models, I: The analysis of one-way transition. Thousand Oaks: SAGE.

Yerkes, Mara; Visser, Jelle 2006: Women's preferences or delineated policies? The development of part-time work in the Netherlands, Germany and the United Kingdom. In: Boulin, Jean-Yves et al. (Eds.): Decent working time - new trends, new issues. Geneva: International Labour Office: 235-262.

Date of submission: 03.07.2019

Date of acceptance: 03.01.2020

Roselinde van der Wiel $(\varangle)$, Prof. Dr. Clara. H. Mulder. Population Research Centre, Faculty of Spatial Sciences, University of Groningen. Groningen, The Netherlands.

E-mail: r.van.der.wiel@rug.nl,c.h.mulder@rug.nl

URL: https://www.rug.nl/staff/r.van.der.wiel/ https://www.rug.nl/staff/c.h.mulder/

Prof. Dr. Helga A.G. de Valk. Netherlands Interdisciplinary Demographic Institute (NIDI)/ KNAW/University of Groningen. The Hague, The Netherlands. E-mail: valk@nidi.nl URL: https://nidi.nl/en/employees/helga-de-valk/ https://www.rug.nl/staff/h.a.g.de.valk/ 


\section{Appendix 1: Coding of partnership status, partnership duration, and motherhood status}

An individual's partnership status was updated the month after a transition occurred; and an individual's motherhood status was updated the same month if a child was born, or the next month if a child had died. If a child was born within a partnership, it was assumed that the partner was the other parent. The duration of the partnership was measured in months and categorised. For partnerships that started prior to wave one, only the start year was recorded, and not the month. These partnerships were assumed to start mid-year. In a small number of cases, the start time of the partnership was unknown. If this was the case for partnerships that existed in wave one, the partnership duration was set to the median duration of other cases who were in a LAT partnership at wave one. For others, the partnership status change was assumed to occur in the middle month between the two waves. Of the handful of respondents who reported having entered a new partnership before ending the previous one, the new partnership was given precedence.

Only the year and not the month of the birth or death of each child was recorded. We assumed that the impact of having a child was present the whole year regardless of the exact time of birth or death, and coded the presence of children as if the births took place in January, and the deaths took place in December. The only exception was for children who were born after the first interview but in the same year as the interview, who were assigned the month of birth following the month of the interview. If a respondent indicated that they did not know whether their child was still alive, the child was disregarded in the coding of parenthood status, as it was deemed unlikely that the child influenced the person's partnership choices. It was not possible to identify re-partnering with the other parent of a child.

\section{Appendix 2: Additional analyses}

Tab. A1: Transition from LAT to co-residence among those with own children. Logistic regression (odds ratios, coefficients, $p$-values)

\begin{tabular}{lcccccc}
\hline & \multicolumn{3}{c}{ Women } & \multicolumn{3}{c}{ Men } \\
& $\mathrm{e}^{\mathrm{b}}$ & $\mathrm{b}$ & $p$ & $\mathrm{e}^{\mathrm{b}}$ & $\mathrm{b}$ & $p$ \\
\hline $\begin{array}{l}\text { Parenthood status and union history } \\
\quad \text { (ref. separated }\end{array}$ & with children) & & & \\
$\quad$ Widowed with children & 0.536 & -0.623 & 0.204 & $2.002^{*}$ & 0.694 & 0.095 \\
$\quad$ Out-of-union children & 0.504 & -0.684 & 0.277 & n.a. & n.a. & n.a. \\
Age of youngest child (ref. age 10-21) & & & & & & \\
$\quad$ Age <10 & 0.922 & -0.082 & 0.779 & 0.598 & -0.514 & 0.331 \\
$\quad 22$ or older & 1.970 & 0.678 & 0.140 & 1.305 & 0.266 & 0.572 \\
Two or more children & 1.004 & 0.004 & 0.987 & 1.168 & 0.155 & 0.730 \\
\hline
\end{tabular}

${ }^{*} \mathrm{p}<0.1,{ }^{* *} \mathrm{p}<0.05,{ }^{* * *} \mathrm{p}<0.01$

Source: NKPS waves 1-4 
142 - Roselinde van der Wiel, Clara. H. Mulder, Helga A.G. de Valk

Tab. A2: Additional descriptive statistics, means of person-months

\begin{tabular}{|c|c|c|c|c|c|}
\hline & $\begin{array}{l}\text { Never in union } \\
\text { and childless }\end{array}$ & $\begin{array}{l}\text { Ever in union } \\
\text { and childless }\end{array}$ & $\begin{array}{c}\text { Separated } \\
\text { with children }\end{array}$ & $\begin{array}{l}\text { Widowed with } \\
\text { children }\end{array}$ & $\begin{array}{l}\text { Out-of-union } \\
\text { children }\end{array}$ \\
\hline & \multicolumn{5}{|c|}{ Women } \\
\hline Age & 29 & 41 & 47 & 56 & 44 \\
\hline Age youngest child & n.a. & n.a. & 17 & 30 & 13 \\
\hline \multirow[t]{2}{*}{ Number of children } & n.a. & n.a. & 2.0 & 2.0 & 2.0 \\
\hline & \multicolumn{5}{|c|}{ Men } \\
\hline Age & 32 & 43 & 52 & 66 & \\
\hline Age youngest child & n.a. & n.a. & 19 & 34 & \\
\hline Number of children & n.a. & n.a. & 2.1 & 2.8 & \\
\hline
\end{tabular}

Source: NKPS waves 1-4 


\section{Comparative Population Studies}

WWW.comparativepopulationstudies.de

ISSN: 1869-8980 (Print) - 1869-8999 (Internet)

\section{Published by}

Prof. Dr. Norbert F. Schneider

Federal Institute for Population Research D-65180 Wiesbaden / Germany

\section{(cc) BY-SA}

2020

\section{Managing Editor}

Prof. Dr. Johannes Huinink

Dr. Katrin Schiefer

\section{Editorial Assistant}

Beatriz Feiler-Fuchs

Wiebke Hamann

\section{Layout}

Beatriz Feiler-Fuchs

E-mail:cpos@bib.bund.de

\section{Scientific Advisory Board}

Karsten Hank (Cologne)

Michaela Kreyenfeld (Berlin)

Marc Luy (Vienna)

Natalie Nitsche (Rostock)

Zsolt Spéder (Budapest)

Rainer Wehrhahn (Kiel)

\section{Board of Reviewers}

Bruno Arpino (Barcelona)

Kieron Barclay (Rostock)

Laura Bernardi (Lausanne)

Gabriele Doblhammer (Rostock)

Anette Eva Fasang (Berlin)

Michael Feldhaus (Oldenburg)

Tomas Frejka (Sanibel)

Alexia Fürnkranz-Prskawetz (Vienna)

Birgit Glorius (Chemnitz)

Fanny Janssen (Groningen)

Frank Kalter (Mannheim)

Stefanie Kley (Hamburg)

Bernhard Köppen (Koblenz)

Anne-Kristin Kuhnt (Duisburg)

Hill Kulu (St Andrews)

Nadja Milewski (Rostock)

Roland Rau (Rostock)

Thorsten Schneider (Leipzig)

Tomas Sobotka (Vienna)

Jeroen J. A. Spijker (Barcelona)

Heike Trappe (Rostock)

Helga de Valk (The Hague)

Sergi Vidal (Barcelona)

Michael Wagner (Cologne) 